
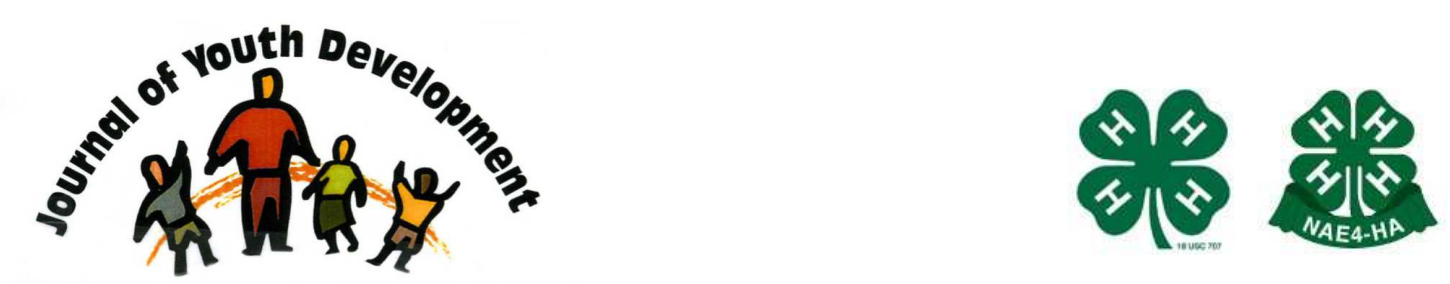

Bridging Research \& Practice

\title{
Voluntary Youth-Serving Organizations: Responding to the Needs of Young People and Society in the Last Century
}

Suzanne M. Le Menestrel

United States Department of Agriculture

slemenestrel@nifa.usda.gov

Lisa A. Lauxman

United States Department of Agriculture

Ilauxman@nifa.usda.gov 


\title{
JOURNAL OF YOUTH DEVELOPMENT \\ bridging research and practice

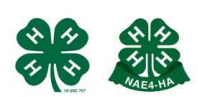

Volume 6, Number 3, Fall 2011

Article 110603FA009

\section{Voluntary Youth-Serving Organizations: Responding to the Needs of Young People and Society in the Last Century}

Suzanne M. Le Menestrel and Lisa A. Lauxman United States Department of Agriculture

\begin{abstract}
As many national youth-serving organizations have either celebrated their $100^{\text {th }}$ anniversaries or are approaching their centennials, we take a step back to celebrate these organizations' accomplishments, but also to examine how youth organizations have responded positively to the youth development philosophy and approach to programming. The focus of this paper is on those organizations in which participation by youth is voluntary.
\end{abstract}

\section{Voluntary Youth-Serving Organizations: How Have They Responded to the Needs of Young People and Society in the Last Century?}

In 2011 many national youth-serving organizations have either celebrated their $100^{\text {th }}$ anniversaries or are approaching their centennials. As we celebrate these organizations' accomplishments, we take note that youth organizations formed in the early part of the $20^{\text {th }}$ century have responded positively to the evolving concept of youth development as a philosophy and way of working in their programs. The large national youth-serving organizations can be characterized as "positive youth development agents" that rely on nonformal educational strategies to offer a broad variety of programs and supports for young people. They build upon key competencies including health, personal, creative/cognitive, vocational, citizenship, and participation (Pittman, 1991). The strategies used to deliver programs are consistent across youth organizations and include the use of small groups, symbols of membership, flexible grouping practices, clear structure, and opportunities for challenge and reward in order to create a sense of achievement (Pittman, 1991).

This article focuses on those national youth-serving organizations that involve voluntary participation by young people ages 5-24 and that have been in existence for a minimum of 50 years. We also focus on those organizations that offer primarily nonformal and informal educational opportunities for youth. Nonformal education is "any organized, systematic, educational activity carried on outside of the framework of the formal system to provide 
selected types of learning to particular subgroups in the population" (Coombs \& Ahmed, 1974). Coombs and Ahmed define informal education as "the lifelong process by which every person acquires and accumulates knowledge, skills, attitudes, and insights from daily experiences and exposure to the environment." Nonformal, informal, and formal education are not necessarily separate learning approaches, but can be considered the predominant learning approaches and often intersect within youth-serving organizations (La Belle, 1982).

The promotion of a youth development perspective has been incubated within these national youth-serving organizations (Costello, Toles, Spielberger, \& Wynn, 2000). We examine how these organizations have evolved over time, whether they experienced a shift from their original mission, and whether a focus on positive youth development, defined as "an intentional, prosocial approach that engages youth within their communities, schools, organizations, peer groups, and families in a manner that is productive and constructive; recognizes, utilizes, and enhances youths' strengths; and promotes positive outcomes for young people by providing opportunities, fostering positive relationships, and furnishing the support needed to build on their leadership strengths" (FindYouthInfo Positive Youth Development, 2011) has always been a significant focus of their mission.

\section{Characteristics of National Youth-Serving Organizations}

The oldest of the youth-serving organizations, including 4-H, Boy Scouts, the Young Women's Christian Association (YWCA), and the Y (formerly known as the Young Men's Christian Association) were established in the United States at the turn of the twentieth century at about the same time as the creation of the public school system (Costello, Toles, Spielberger, \& Wynn, 2000). This was the same period in history in which youth were viewed as problems rather than as assets and when psychologist G. Stanley Hall's theory of adolescence as a period of "storm and stress" (Hall, 1904) influenced many institutions and the general public.

At the turn of the century, many of the youth organizations were focused on addressing youth in crisis-poverty, homelessness, entry into the judicial system, post-war, etc. However, as seen in Table 1, many of the youth-serving organizations also focused on meeting the developmental needs of young people through skills training, creating educational opportunities and jobs. At the present time, nearly all of the current mission statements now include terms such as "potential," "build" and "inspire." In an assessment of mission statements of major national youth-serving organizations, Pittman and Wright (1991) identified that four of the following five competencies were common across these organizations:

- health and physical competence;

- personal and social competence;

- cognitive creative competence;

- vocational competence; and

- citizenship competence.

The voluntary nature of these organizations indicates that they must be of interest to and relevant for the youth that they target. Those organizations that have been successful offer choice and emphasize a sense of mastery and independence (Costello, Toles, Spielberger, \& Wynn, 2000). 
Table 1

Emerging Articulation of Youth Development

\begin{tabular}{|c|c|c|c|c|}
\hline Organization & $\begin{array}{l}\text { Original } \\
\text { Purpose }\end{array}$ & Current Mission & History & Other \\
\hline $\begin{array}{l}\text { 4-H (4-H National } \\
\text { Headquarters, } \\
\text { 2011) }\end{array}$ & $\begin{array}{l}\text { To teach youth } \\
\text { to understand } \\
\text { and appreciate } \\
\text { rural life. }\end{array}$ & $\begin{array}{l}\text { 4-H seeks to } \\
\text { promote positive } \\
\text { youth } \\
\text { development, } \\
\text { facilitate learning } \\
\text { and engage youth } \\
\text { in the work of their } \\
\text { community through } \\
\text { the Cooperative } \\
\text { Extension } \\
\text { Service to enhance } \\
\text { the quality of life. }\end{array}$ & $\begin{array}{l}\text { Founded between } \\
1890 \text { and } 1900 . \\
\text { With passage of the } \\
\text { Smith-Lever Act of } \\
1914, \text { county agents } \\
\text { and leaders } \\
\text { organized 4-H clubs. } \\
\text { 4-H is a public- } \\
\text { private partnership } \\
\text { between the U.S. } \\
\text { Department of } \\
\text { Agriculture, the land } \\
\text { grant universities' } \\
\text { Cooperative } \\
\text { Extension System, } \\
\text { and the National 4-H } \\
\text { Council. }\end{array}$ & $\begin{array}{l}\text { The term " } 4-\mathrm{H}^{\prime \prime} \\
\text { was first used in a } \\
1918 \text { federal } \\
\text { publication. The } \\
\text { name was adopted } \\
\text { formally in } 1924 .\end{array}$ \\
\hline $\begin{array}{l}\text { Big Brothers Big } \\
\text { Sisters of America } \\
\text { (Big Brothers Big } \\
\text { Sisters About Us, } \\
\text { 2011) }\end{array}$ & $\begin{array}{l}\text { Provide support } \\
\text { for troubled } \\
\text { boys moving } \\
\text { through the } \\
\text { court system. }\end{array}$ & $\begin{array}{l}\text { To provide children } \\
\text { facing adversity } \\
\text { with strong and } \\
\text { enduring, } \\
\text { professionally } \\
\text { supported one-to- } \\
\text { one relationships } \\
\text { that change their } \\
\text { lives for the better, } \\
\text { forever. }\end{array}$ & $\begin{array}{l}\text { Founded in } 1904 \text { by } \\
\text { a court clerk, Ernest } \\
\text { Coulter, who saw } \\
\text { many boys coming } \\
\text { through the } \\
\text { courtroom and } \\
\text { recognized that } \\
\text { caring adults could } \\
\text { help support these } \\
\text { troubled youth. Big } \\
\text { Brothers Association } \\
\text { and Big Sisters } \\
\text { International } \\
\text { merged in } 1977 .\end{array}$ & $\begin{array}{l}\text { Currently operates } \\
\text { in all } 50 \text { states and } \\
12 \text { countries. Big } \\
\text { Brothers Big } \\
\text { Sisters } \\
\text { International was } \\
\text { founded in } 1998 .\end{array}$ \\
\hline $\begin{array}{l}\text { Boy Scouts of } \\
\text { America (Costello, } \\
\text { et al., 2000). }\end{array}$ & $\begin{array}{l}\text { Original mission } \\
\text { was focused on } \\
\text { training boys to } \\
\text { be self-sufficient } \\
\text { and to provide } \\
\text { for themselves. }\end{array}$ & $\begin{array}{l}\text { To provide an } \\
\text { educational } \\
\text { program for boys } \\
\text { and young adults to } \\
\text { build character, to } \\
\text { train in the } \\
\text { responsibilities of } \\
\text { participating } \\
\text { citizenship, and to } \\
\text { develop personal } \\
\text { fitness (Boy Scouts } \\
\text { of America, 2011). }\end{array}$ & $\begin{array}{l}\text { Founded in } 1908 \text { by } \\
\text { Robert S. Baden } \\
\text { Powell in England. } \\
\text { Was incorporated as } \\
\text { the Boy Scouts of } \\
\text { America in } 1910 .\end{array}$ & $\begin{array}{l}\text { Currently have } \\
\text { more than } 250 \\
\text { million youth } \\
\text { participating (BSA } \\
\text { History, 2011) }\end{array}$ \\
\hline
\end{tabular}




\begin{tabular}{|c|c|c|c|c|}
\hline Organization & $\begin{array}{l}\text { Original } \\
\text { Purpose }\end{array}$ & Current Mission & History & Other \\
\hline $\begin{array}{l}\text { Boys and Girls } \\
\text { Clubs of America } \\
\text { (Boys and Girls } \\
\text { Clubs of America, } \\
2011 \text { ) }\end{array}$ & $\begin{array}{l}\text { To serve poor } \\
\text { and immigrant } \\
\text { children and } \\
\text { youth in large } \\
\text { urban centers } \\
\text { (Witt, 2005). }\end{array}$ & $\begin{array}{l}\text { To enable all young } \\
\text { people, especially } \\
\text { those who need us } \\
\text { most, to reach their } \\
\text { full potential as } \\
\text { productive, caring, } \\
\text { responsible citizens. }\end{array}$ & $\begin{array}{l}\text { The first boys club } \\
\text { was organized in } \\
\text { Hartford, } \\
\text { Connecticut in } 1860 . \\
\text { Several clubs } \\
\text { federated and } \\
\text { became the Boys } \\
\text { Clubs of America in } \\
1931 \text {. The charter } \\
\text { was amended by } \\
\text { Congress in } 1990 \text { to } \\
\text { include girls and } \\
\text { became the Boys } \\
\text { and Girls Clubs of } \\
\text { America. }\end{array}$ & $\begin{array}{l}\text { Character } \\
\text { development has } \\
\text { been an important } \\
\text { part of the mission } \\
\text { of BGCA since its } \\
\text { founding. }\end{array}$ \\
\hline $\begin{array}{l}\text { Camp Fire USA } \\
\text { (Camp Fire USA, } \\
\text { 2011) }\end{array}$ & $\begin{array}{l}\text { Originally } \\
\text { intended to } \\
\text { provide for girls } \\
\text { what Boy Scouts } \\
\text { provided for } \\
\text { boys (Witt, } \\
\text { 2005). }\end{array}$ & $\begin{array}{l}\text { Camp Fire USA } \\
\text { builds caring, } \\
\text { confident youth } \\
\text { and future leaders. }\end{array}$ & $\begin{array}{l}\text { Founded by Luther } \\
\text { and Charlotte Gulick } \\
\text { in } 1910 .\end{array}$ & $\begin{array}{l}\text { The organization } \\
\text { started as "Camp } \\
\text { Fire Girls" and } \\
\text { became co- } \\
\text { educational in } \\
1975 .\end{array}$ \\
\hline $\begin{array}{l}\text { Catholic Charities } \\
\text { (Catholic Charities } \\
\text { USA, 2011) }\end{array}$ & $\begin{array}{l}\text { Focused on } \\
\text { charitable } \\
\text { ministries for } \\
\text { the poor. }\end{array}$ & $\begin{array}{l}\text { Focus on reducing } \\
\text { poverty, supporting } \\
\text { families, and } \\
\text { empowering } \\
\text { communities. }\end{array}$ & $\begin{array}{l}\text { Founded in } 1910 \text { by } \\
\text { Catholic University } \\
\text { of America. } \\
\text { Expanded reach and } \\
\text { currently serves } \\
\text { over } 9 \text { million } \\
\text { people. }\end{array}$ & $\begin{array}{l}\text { Focuses on } \\
\text { advocacy, } \\
\text { networking, } \\
\text { national voice, } \\
\text { financial support } \\
\text { and leadership and } \\
\text { disaster response. }\end{array}$ \\
\hline $\begin{array}{l}\text { Girl Scouts of the } \\
\text { United States of } \\
\text { America (Girl Scout } \\
\text { History, 2011) }\end{array}$ & $\begin{array}{l}\text { The original } \\
\text { mission was to } \\
\text { "train girls to } \\
\text { take their } \\
\text { rightful places in } \\
\text { life, first as good } \\
\text { women, then as } \\
\text { good citizens, } \\
\text { wives and } \\
\text { mothers." } \\
\text { (Levey \& } \\
\text { Degenhardt, } \\
\text { 2002) }\end{array}$ & $\begin{array}{l}\text { To build girls of } \\
\text { courage, } \\
\text { confidence and } \\
\text { character, who } \\
\text { make the } \\
\text { world a better } \\
\text { place. }\end{array}$ & $\begin{array}{l}\text { Founded in } 1912 \text { by } \\
\text { Juliette Gordon Low } \\
\text { and incorporated in } \\
1915 .\end{array}$ & $\begin{array}{l}\text { Has a membership } \\
\text { of } 3.2 \text { million girls } \\
\text { and adults today. }\end{array}$ \\
\hline
\end{tabular}




\begin{tabular}{|c|c|c|c|c|}
\hline Organization & $\begin{array}{l}\text { Original } \\
\text { Purpose }\end{array}$ & Current Mission & History & Other \\
\hline $\begin{array}{l}\text { Girls Incorporated } \\
\text { (Girls Inc. The } \\
\text { Early Years, 2011) }\end{array}$ & $\begin{array}{l}\text { To serve needs } \\
\text { of rural girls and } \\
\text { women. }\end{array}$ & $\begin{array}{l}\text { Girls Incorporated } \\
\text { is a nonprofit } \\
\text { organization that } \\
\text { inspires all girls to } \\
\text { be strong, smart, } \\
\text { and bold }{ }^{\text {SM }} \text { through } \\
\text { a network of local } \\
\text { organizations in the } \\
\text { United States and } \\
\text { Canada. }\end{array}$ & $\begin{array}{l}\text { First affiliate formed } \\
\text { in } 1864 \text { in } \\
\text { Waterbury, } \\
\text { Connecticut. First } \\
\text { formed to meet } \\
\text { needs of rural girls } \\
\text { and women who } \\
\text { moved to urban } \\
\text { areas for jobs in } \\
\text { textile mills and } \\
\text { factories. In 1945, } \\
\text { formed into Girls } \\
\text { Clubs of America. }\end{array}$ & $\begin{array}{l}\text { Programming in } \\
\text { early days focused } \\
\text { on homemaking } \\
\text { skills and } \\
\text { recreation. The } \\
\text { original focus was } \\
\text { maintained } \\
\text { through the } 1960 \text { s. } \\
\text { In } 1974 \text {, they } \\
\text { reexamined their } \\
\text { original mission. } \\
\text { Name was } \\
\text { changed to Girls } \\
\text { Incorporated in } \\
1990 .\end{array}$ \\
\hline $\begin{array}{l}\text { National Urban } \\
\text { League (National } \\
\text { Urban League, } \\
\text { 2011) }\end{array}$ & $\begin{array}{l}\text { Focus on } \\
\text { educational and } \\
\text { employment } \\
\text { opportunities for } \\
\text { African } \\
\text { Americans. }\end{array}$ & $\begin{array}{l}\text { The mission of the } \\
\text { Urban League } \\
\text { movement is to } \\
\text { enable African } \\
\text { Americans to } \\
\text { secure economic } \\
\text { self-reliance, parity, } \\
\text { power and civil } \\
\text { rights. }\end{array}$ & $\begin{array}{l}\text { Founded in } 1911 \text { as } \\
\text { the National League } \\
\text { on Urban Conditions } \\
\text { Among Negroes. } \\
\text { The name was } \\
\text { shortened to } \\
\text { National Urban } \\
\text { League in } 1920 \text {. } \\
\text { Began by counseling } \\
\text { southern Black } \\
\text { migrants, training } \\
\text { Black social workers } \\
\text { and focusing on } \\
\text { educational and } \\
\text { employment } \\
\text { opportunities for } \\
\text { blacks. }\end{array}$ & $\begin{array}{l}\text { Have a youth } \\
\text { development } \\
\text { framework and } \\
\text { guide that is used } \\
\text { by affiliates during } \\
\text { the out-of-school } \\
\text { time hours in three } \\
\text { program areas: } \\
\text { Intellectual, social, } \\
\text { and } \\
\text { physical/relational. }\end{array}$ \\
\hline $\begin{array}{l}\text { Save the Children } \\
\text { USA (Save the } \\
\text { Children USA, } \\
\text { 2011) }\end{array}$ & $\begin{array}{l}\text { Focus on } \\
\text { immediate } \\
\text { needs (families } \\
\text { in rural } \\
\text { Appalachia } \\
\text { struggling to } \\
\text { survive after the } \\
\text { Great } \\
\text { Depression). }\end{array}$ & $\begin{array}{l}\text { To create lasting, } \\
\text { positive change in } \\
\text { the lives of children } \\
\text { in need in the } \\
\text { United States and } \\
\text { around the world. }\end{array}$ & $\begin{array}{l}\text { Modeled after British } \\
\text { organization created } \\
\text { to serve starving } \\
\text { children after World } \\
\text { War I. Created in } \\
1932 \text { in the U.S. } \\
\text { Initial focus was on } \\
\text { serving children and } \\
\text { families in } \\
\text { Appalachia. }\end{array}$ & $\begin{array}{l}\text { Focus on early } \\
\text { childhood } \\
\text { education, literacy, } \\
\text { physical activity, } \\
\text { and nutrition. }\end{array}$ \\
\hline
\end{tabular}




\begin{tabular}{|c|c|c|c|c|}
\hline Organization & $\begin{array}{l}\text { Original } \\
\text { Purpose }\end{array}$ & Current Mission & History & Other \\
\hline $\begin{array}{l}\text { The Salvation } \\
\text { Army (Salvation } \\
\text { Army The History, } \\
\text { 2011) }\end{array}$ & $\begin{array}{l}\text { Focus on the } \\
\text { poor and } \\
\text { homeless. }\end{array}$ & $\begin{array}{l}\text { An evangelical part } \\
\text { of the universal } \\
\text { Christian Church. } \\
\text { Its message is } \\
\text { based on the Bible. } \\
\text { Its ministry is } \\
\text { motivated by the } \\
\text { love of God. Its } \\
\text { mission is to preach } \\
\text { the gospel of Jesus } \\
\text { Christ and to meet } \\
\text { human needs in His } \\
\text { name without } \\
\text { discrimination. }\end{array}$ & $\begin{array}{l}\text { William Booth, a } \\
\text { minister, founded } \\
\text { the Salvation Army } \\
\text { in } 1865 \text {. He } \\
\text { stopped preaching } \\
\text { in church and } \\
\text { focused on the poor } \\
\text { and homeless. The } \\
\text { organization was } \\
\text { referred to as the } \\
\text { Christian Mission } \\
\text { until } 1878 \text {. }\end{array}$ & $\begin{array}{l}\text { Operates in } 106 \\
\text { countries. }\end{array}$ \\
\hline $\begin{array}{l}\text { Volunteers of } \\
\text { America } \\
\text { (Volunteers of } \\
\text { America Our } \\
\text { History, 2011) }\end{array}$ & $\begin{array}{l}\text { Focus on } \\
\text { housing for } \\
\text { individuals living } \\
\text { in poverty. }\end{array}$ & $\begin{array}{l}\text { A ministry of } \\
\text { service that } \\
\text { includes nearly } \\
16,000 \text { paid, } \\
\text { professional } \\
\text { employees } \\
\text { dedicated to } \\
\text { helping those in } \\
\text { need rebuild their } \\
\text { lives and reach } \\
\text { their full potential. }\end{array}$ & $\begin{array}{l}\text { Founded in } 1896 \text { by } \\
\text { Ballington and Maud } \\
\text { Booth. In the early } \\
\text { part of the } 20^{\text {th }} \\
\text { century, Volunteers } \\
\text { of America focused } \\
\text { on tenement } \\
\text { districts and focused } \\
\text { on providing } \\
\text { opportunities for } \\
\text { people living in } \\
\text { poverty, including } \\
\text { summer camps. }\end{array}$ & $\begin{array}{l}\text { One of their } \\
\text { current mission } \\
\text { areas is to focus } \\
\text { on services for } \\
\text { disadvantaged and } \\
\text { disconnected } \\
\text { children and } \\
\text { youth. }\end{array}$ \\
\hline $\begin{array}{l}\text { YMCA (Costello, et } \\
\text { al., 2000) }\end{array}$ & $\begin{array}{l}\text { Original mission: } \\
\text { to create a club } \\
\text { for young } \\
\text { working men. } \\
\text { Focused on } \\
\text { Bible study and } \\
\text { prayer in } \\
\text { England. } \\
\text { In the U.S., was } \\
\text { originally } \\
\text { focused on } \\
\text { providing a } \\
\text { home away } \\
\text { from home for } \\
\text { sailors and } \\
\text { merchants (The } \\
\text { Y: Yesterday, } \\
\text { today, tomorrow } \\
\text { for good, 2011) }\end{array}$ & $\begin{array}{l}\text { To put Christian } \\
\text { principles into } \\
\text { practice through } \\
\text { programs that build } \\
\text { a healthy spirit, } \\
\text { mind and body for } \\
\text { all. }\end{array}$ & $\begin{array}{l}\text { Founded in } 1844 \text { in } \\
\text { England. Brought to } \\
\text { North America in } \\
1851 .\end{array}$ & $\begin{array}{l}\text { Has a national } \\
\text { framework; each } \\
\text { branch is } \\
\text { autonomous. Now } \\
\text { known as "the Y." }\end{array}$ \\
\hline
\end{tabular}




\begin{tabular}{|l|l|l|l|l|}
\hline Organization & $\begin{array}{l}\text { Original } \\
\text { Purpose }\end{array}$ & Current Mission & History & Other \\
\hline YWCA (YWCA, & $\begin{array}{l}\text { Original mission: } \\
\text { to provide for } \\
\text { young working } \\
\text { women. }\end{array}$ & $\begin{array}{l}\text { Current mission is } \\
\text { YWCA is dedicated } \\
\text { to eliminating } \\
\text { racism, } \\
\text { empowering } \\
\text { women and } \\
\text { promoting peace, } \\
\text { justice, freedom } \\
\text { and dignity for all. }\end{array}$ & Founded in 1877. & $\begin{array}{l}\text { Independent from } \\
\text { the YMCA. }\end{array}$ \\
& & & \\
\hline
\end{tabular}

\section{New Voices}

The prevailing notion of adolescence for most of the last century was one of "storm and stress," as posited by theorists including G. Stanley Hall, Anna Freud, and Erik Erikson (Lerner, 2007). It was not until the 1960 s and 1970s, that researchers and theorists began to consider "healthy" adolescent development (Lerner, 2007). In 1973, Gisela Konopka identified eight fundamental requirements for healthy adolescent development. These included: (1) participate as a responsible member of society; (2) gain experience in decision making; (3) have a sense of belonging; (4) have the opportunity to reflect on oneself in relationship to others; (5) formulate a value system; (6) try out different roles; (7) develop a sense of accountability; and (8) cultivate a capacity to enjoy life.

\section{Key Reports}

Two key reports produced in the late eighties, The Forgotten Half and $A$ Matter of Time, described what kinds of youth outcomes were desirable to produce as well as the community supports that were needed to achieve these outcomes (William T. Grant Foundation Commission on Work, Family, and Citizenship, 1988; Carnegie Council on Adolescent Development Task Force on Education of Young Adolescents, 1989, January). In 1994, the Carnegie Council on Adolescent Development issued a pivotal wake-up call noting that the three institutions that once met adolescents' needs (families, schools, and community organizations) were "slow to adapt to new social realities." (Carnegie Council on Adolescent Development, 1994, April). These "social realities" included strained capacity of parents and caregivers, a societal demand for highly skilled workers prepared to compete in the global workplace, poverty, crime, and other societal ills. At that time, the Carnegie Council commented on the important role that youth organizations can play in the lives of young people but urged programs to do much more to promote positive youth development, especially for disadvantaged youth. These organizations are often challenged by lack of relevance to diverse audiences and older youth, lack of financial resources, and difficulty in recruiting and preparing paid and volunteer adult leaders. The Carnegie Council called for programs to address the following "universal requirements of adolescents:" (1) Health and physical well-being; (2) personal and social competence; (3) cognitive and educational competence; (4) preparation for work; and (5) leadership and citizenship.

These reports were significant as they called for the preparation of youth to achieve these outcomes rather than the prevention or intervention of problems (Pittman \& Irby, 2008). In the decade following the release of these reports, Pittman and Irby observe that there has been "an increased acceptance of youth development as a broad goal requiring intentional monitoring and intervention." 


\section{Shifting Paradigms}

The major themes of the field of positive youth development were defined in the mid- to late90s and it took approximately a decade to give these themes the name positive youth development. The 1990s were a period of "shifting paradigms," according to Pittman and Irby and as such, youth-serving organizations changed course as well. This paradigm shift includes six assertions:

(1) moving beyond prevention to promotion of skills, confidence, character, connection to family, peers, and community;

(2) moving beyond quick fixes and strengthening engagement of youth and adults in the developmental process;

(3) moving beyond schools to include families, neighborhoods, community organizations, the workplace and service agencies;

(4) moving beyond coordination to creating a vision;

(5) moving beyond labeling of youth as "at risk;" and

(6) viewing youth not as recipients of services but as contributors to their own development (Pittman \& Irby, 2008).

In the mid-1990s, a group of researchers and practitioners described the five competencies or " $C$ 's" that could prepare youth for a successful transition to adulthood. These include:

Competence, the ability to act effectively in a number of different contexts such as school and work; Confidence, an internal, overall sense of worth; Connection, positive bonds with others and institutions; Character, a sense of internalized values; and Caring, a sense of empathy and sympathy for others. A sixth C, Contribution, giving back to one's community through service, was added later (Lerner, 2007).

\section{The Blue Book}

In 2002, the National Academies of Science issued a landmark consensus study that outlined eight features of positive developmental settings. These include: physical and psychological safety; appropriate structure; supportive relationships; opportunities to belong; positive social norms; support for efficacy and mattering; and opportunities for skill building (National Research Council and Institute of Medicine, 2002). While these characteristics are drawn from theory and research on all formal and informal settings with which youth may interact, the articulation of these characteristics has aided youth-serving organizations in moving forward with assessments of program quality and how youth perceive these characteristics in their interactions with programs. This emphasis on quality has implications for point-of-service quality as well as for organizational structures that support quality.

\section{Youth Organizations' Response to Societal Changes}

Youth-serving organizations have responded to "social realities" by shifting programmatic content from a focus on "survival skills" to a focus on "life skills" and preparing youth for successful transitions to adulthood. They are also reaching out to populations of youth that may not have been traditionally engaged or served by their organizations. Some youth-serving organizations were established as recreation-focused and have been shifting their missions to nonformal education and workforce preparation. One example of how 4-H is addressing the societal demand for a highly skilled workforce is through its national Science initiative. In particular, a 4-H Science in Urban Communities initiative has been identifying promising and 
best practices in urban science including programming, partnerships, resource development and staffing (4-H Science in Urban Communities, 2011).

Many national youth organizations are challenged to meet the needs of middle-school and highschool aged youth. As adolescents develop, their interests and needs change. Programs for older youth need to provide educational programs that prepare youth to navigate across multiple cultural settings; opportunities to mentor younger youth; meaningful leadership roles; and programs that help them focus on educational and career goals. Youth-serving organizations are also addressing meeting the needs of underserved populations. For many of the organizations in Table 1, such as Catholic Charities, National Urban League, and Save the Children, this has been part of their focus from their inception.

Other youth-serving organizations have changed and adapted their missions over time to address the needs of youth who might not traditionally be engaged in their programs, either because of lack of interest or lack of access. For example, Girls Inc., founded in 1864 as Girls Club, has addressed the changing needs of girls in response to social changes in the U.S. that impacted girls' perceptions of who they were and who they could become. This is evident in the evolution of the mission and the types of programming offered to girls. The mission statement has evolved over the past 147 years from one that broadly sought "to better conditions for working girls" to a focus on homemaking, then intellect, character development, and to what is now a succinct focus on a holistic mission of "inspiring all girls to be strong, smart, and bold". These changes are connected to social movements that helped advance women's rights and broaden perceptions of what girlhood and womanhood meant related to family, career, and social roles.

Similarly, Girl Scouts of the USA, founded in 1912 by Juliette Gordon Low, before women had the right to vote in the United States, was intended to present girls with new opportunities to develop in ways that were not available otherwise in society. Girl leadership development has been at the heart of Girl Scouting since its founding, when Low recognized that developing girls' leadership abilities was critical for ensuring they would be the change-makers of the future. The mission statement of Girl Scouting has evolved over the past 100 years from one that proclaimed to help girls to become "good citizens" to one that intentionally focuses on the qualities and skills that develop girl leadership in the $21^{\text {st }}$ century: "Girl Scouting builds girls of courage, confidence and character who make the world a better place."

\section{Funding Support as Key to Responsiveness}

National youth-serving organizations operate with a significant amount of autonomy and flexibility (Costello, et al., 2000). Funding often comes from diverse sources including public and private and most organizations allow their local affiliates a substantial amount of independence. Most rely heavily on volunteers because of limited resources which forces them to be flexible.

While national youth-serving organizations are accustomed to operating on shoestring budgets (Newman, Smith, \& Murphy, 2000), several societal factors have impacted the public's investment in youth development. These include: the "devaluation of adolescents," a lack of consensus on youth development, a lack of integrated structure for youth services, and lack of sufficient and protected funding (Newman, et al., 2000).

More than a decade ago, Quinn (1999) reflected that youth-serving organizations faced four challenges related to funding: diversity, instability, inadequacy and inequity. Diversity was 
defined as the different funding patterns for different types of youth organizations. Instability related to the unstable funding base where there was no major permanent public funding stream and organizations faced the risks of changes from political winds and/or a new administration. Public support for youth organizations in the late 1980's and early 1990's came from "discretionary" grant programs. Inadequacy as a challenge was due to youth development organizations competing with one another for a slice of the relatively small public support funding pie especially when compared to youth development programs in Britain, Norway and Sweden which received regular financial public support (Sherraden, 1992). Inequity referred to the access of service delivery based upon local programs' ability to solicit funds creating a disparity between poor and affluent communities. Quinn (1999) concluded that major public funding cutbacks in human services would cause youth organizations to diversify their funding sources, compete harder for available grant dollars, increase efforts to solicit contributions from individuals and corporations, and develop strategies for earning income.

Leonard Stern's exploratory study (1992) surveyed funding streams for youth-serving organizations. Categories included federal, state and local government, United Way, fees (service/program/membership), foundations (national, community, corporation, other), donations (corporate and individual), and fund-raising (events, product/program sales). Newman and his colleagues (2000) listed in their essay regarding the cost and financing of youth development four general sources: private (families and individuals); philanthropy; local, state and federal governments; and the business community.

National youth-serving organizations have employed various strategies to diversify funding sources. Some strategies focus on program accountability, messaging, and board accountability. Campbell and Menezes (2010) outline "Four Pillars of Growth for Youth-Serving Non-Profits to be:

(1) create strategic operating plans that allow for organizations to be "opportunistic" and build capabilities in data systems, evaluation, advocacy, and staff capacity,

(2) demonstrate clear programmatic results,

(3) market purposefully to specific funders to influence and shape funding streams with governmental funders and build relationships with private funders through targeted messaging and

(4) actively engaging board members, strengthening their commitment, leveraging skills and expertise, and casting a wider net for resources.

Capacity building is a theme outlined as well in Silloway's (2010) strategy brief with approaches that assist in building accurate overhead rates into contracts and grants, accessing funding to support capacity building, pursuing technical assistance and promoting leveraging of administrative resources.

Diversification of funding by national youth-serving organizations includes Boys and Girls Clubs' pursuit and receipt of federal dollars with the Office of Juvenile Justice and Delinquency Prevention (OJJDP). Land-grant extension systems have turned to program development fees for 4-H and increasing expectation to garner support through public and private grant dollars for programming. Girl Scout councils that maintain their cookie product sales have had to increase prices while also soliciting programming support through grants and relationships with women in science organizations. The latest recession has led to program fees to be charged and social enterprise activities to generate new revenue and fill budget gaps. Sliding-scale fees 
have been implemented as well as charging fees for transportation. Charging fees can help with voluntary organizations' enrollment commitment. Youth-serving organizations' diversified funding streams now include a mix of public and private dollars.

Diversification can lead to charges that youth-serving organizations suffer mission drift and are chasing the dollars. These transitions may be perceived by clientele, program staff and former participants as deviating from serving the best interests of youth, especially as youth-serving organizations seek out corporate sponsorship, celebrity spokespersons, and licensing arrangements. In addition, individuals are concerned that funding diversification leads to a possible loss of youth voice and engagement and that youth participants are being exploited to build the messaging for targeted funders.

\section{Volunteers and the Youth Work Profession}

Over the past 100 years, the nature of volunteerism has changed significantly as has the nature of the youth work profession. The early part of the last century was characterized by progressive social reform in which the middle class became increasingly aware of and concerned by the conditions in which the poor were living (Ellis \& Campbell, 2005). At the turn of the last century, concern for children's welfare was an issue that attracted many volunteers to organizations such as the Big Brothers Association. Juvenile courts were also staffed by volunteers. At that time in history, rural volunteers were drawn to youth programs, including the early precursors of 4-H: demonstration, corn, and canning clubs (Ellis \& Campbell, 2005). Similarly, Boy Scouts, Girl Scouts, and Camp Fire Girls, all established in the U.S. at the turn of the century, drew on volunteers to lead planning bodies and to run local groups (Ellis \& Campbell, 2005).

Along with the articulation of positive youth development as a field has come the professionalization of youth work. While many of the youth-serving organizations in Table 1 rely significantly on volunteers, these organizations, including Girl Scouts, Boy Scouts, 4- $\mathrm{H}$, Camp Fire USA, the $Y$ and YWCA have sought to strengthen their professional development systems for their workforce over the past 20 years (Johnston Nicholson, Houchin, \& Stegall, 2004). Early efforts were limited in their focus, but there have been several significant initiatives that have served to build consensus on essential competencies for youth work practice (Quinn, 2004).

\section{Conclusion}

National youth-serving organizations have responded encouragingly to the changing needs of youth and have been incorporating youth development as a philosophy into their programming. As we mentioned in this paper, the words "healthy" adolescent development did not come into the common vernacular until the 1960s. Since then, several important reports and studies have called for an increased engagement and responsiveness on the part of these youth organizations to address critical social realities of young people. As shown in Table 1, youthserving organizations have been meeting the challenge by shifting their original purpose or mission to one that is focused on developing life skills, creating sustainable change, and helping youth transition successfully into adulthood.

As these voluntary youth-serving organizations move into the next 100 years of serving youth and their families, there will be a number of different societal factors and challenges that they will need to address and respond to. For example, Stern's (1992) recommendation and the strategies employed to target funders ought to be reconsidered. He raised the question of what 
impact funders' priorities have on youth-serving organizations. "Do they follow the dollar or do they simply play the funder's game to keep working at the mission they have established?" According to Stern, (1992) agencies that could demonstrate their effectiveness would survive and prosper. The study's recommendations included:

1) increased, and consolidated government support inclusive of possible taxation for youth development, specific legislation for Young Americans, support for a cadre of trained youth development workers, and youth development block grants;

2) principles, guidelines and standards for youth serving organizations;

3) a level playing field for fundraising competition;

4) a national non-governmental center for youth development; and

5) accountability measures and data.

As we look at the changing role of national youth-serving organizations, funding diversification may keep youth-serving organizations alive, yet leave youth neither engaged nor served. Perhaps it is time to dust off and revisit the recommendations for funding, and review them in the light of building capacity and competency of youth-serving organizations to ensure program quality and access for all youth.

Another significant societal challenge that youth-serving organizations will need to address is the fact that youth are taking much longer than in past generations to transition into a selfsufficient adulthood. In the 1950s, for instance, it was normative for young people to leave home at an early age. The longer transition to adulthood that youth are finding themselves in now puts an added strain on families as well as those institutions that support youth (Settersten \& Ray, 2010). This may lead some youth-serving organizations to reconsider their membership age rules and/or consider educational and career pathways for those youth who age out of the organization (e.g., Girl Scouts, Boy Scouts, 4-H, etc.).

In sum, national youth-serving organizations have a long and proud history serving youth and their families. As rapidly as society is changing because of advances in technology and other "social realities," youth-serving organizations will need to balance the "traditional" spirit and unique cultures of their organizations and at the same time, meet these new realities with nimbleness and compassion.

Acknowledgement: We would like to acknowledge the assistance of Catherine Cushinberry, Girls Incorporated, Pamela Cruz and Michael Conn, Girl Scouts of the USA, and special issue editor Joyce Walker, University of Minnesota, in the preparation of this manuscript.

\section{References}

4-H National Headquarters. (2011). Retrieved March 7, 2011, from 4-H National Headquarters: http://www.national4-hheadquarters.gov/

4-H Science in Urban Communities. (2011, May 31). 4-H Science in Urban Communities Promising Practices Guide. Retrieved May 31, 2011, from http://urban4hscience.rutgers.edu 
Big Brothers Big Sisters About Us. (2011). Retrieved March 10, 2011, from Big Brothers Big Sisters:

http://www.bbbs.org/site/c.9iILI3NGKhK6F/b.5962351/k.42EB/We are here to start somethin g.htm

Boy Scouts of America. (2011). At a Glance. Retrieved June 20, 2011, from Boy Scouts of America: http://www.scouting.org/Media/MediaKit/AtaGlance.aspx

Boys and Girls Clubs of America. (2011). Retrieved March 7, 2011, from Boys and Girls Clubs of America: http://www.bgca.org/whoweare/Pages/History.aspx

BSA History. (2011). Retrieved January 15, 2011, from Boy Scouts of America:

http://scouting.org/About/FactSheets/BSA History.aspx

Camp Fire USA. (2011). Retrieved March 10, 2011, from Camp Fire USA:

http://www.campfireusa.org/

Campbell, K., \& Menezes, R. (2010). Four Pillars of Growth for Youth-Serving Non-Profits. Washington, DC: The Bridgespan Group.

Carnegie Council on Adolescent Development. (1994, April). A Matter of Time: Risk and Opportunity in the Out-of-School Hours. New York: Carnegie Corporation of New York.

Carnegie Council on Adolescent Development Task Force on Education of Young Adolescents. (1989, January). Turning Points: Preparing American Youth for the 21st Century. New York: Carnegie Corporation of New York.

Catholic Charities USA. (2011). Retrieved January 15, 2011, from Catholic Charities USA: http://www.catholiccharitiesusa.org/NetCommunity/Page.aspx?pid=1408

Coombs, P.H., \& Ahmed, M. (1974). Attacking Rural Poverty: How Nonformal Education Can Help. Baltimore, MD: Johns Hopkins University Press.

Costello, J., Toles, M., Spielberger, J., \& Wynn, J. (2000). History, ideology and structure shape the organizations that shape youth. In N. Jaffe (Ed.), Youth Development: Issues, Challenges and Directions (pp. 186-231). Philadelphia, PA: Public/Private Ventures.

Ellis, S.J., \& Campbell, K.H. (2005). By the People: A History of Americans as Volunteers.

Philadelphia: Energize, Inc.

FindYouthInfo Positive Youth Development. (2011). Retrieved March 14, 2011, from

FindYouthInfo: http://www.findyouthinfo.gov/topic pyd.shtml

Girl Scout History. (2011). Retrieved March 7, 2011, from Girl Scouts of the United States of America: http://www.girlscouts.org/who we are/history/

Girls Inc. The Early Years. (2011). Retrieved March 7, 2011, from Girls Inc.: http://www.girlsinc.org/about/history/early-years.html

Hall, S.G. (1904). Adolescence. New York: Appleton.

Johnston Nicholson, H., Houchin, S., \& Stegall, B. (2004). Professional development in national organizations: Insights from Girls Incorporated. New Directions for Youth Development, pp. 6573. 
Konopka, G. (1973). Requirements for healthy development of adolescent youth. Adolescence, $8(31), 291-316$.

La Belle, T.J. (1982). Formal, nonformal and informal education: A holistic perspective on lifelong learning. International Review of Education, 28, 159-175.

Lerner, R.M. (2007). The Good Teen: Rescuing Adolescence from the Myths of the Storm and Stress Years. New York: Random House.

Levey, M., \& Degenhardt, M. (2002). Highlights in Girl Scouting 1912-2001. New York: Girl Scouts of the United States of America.

National Research Council and Institute of Medicine. (2002). Community Programs to Promote Youth Development. (J. Eccles, \& J. A. Gootman, Eds.) Washington, DC: National Academy Press.

National Urban League. (2011). Retrieved March 10, 2011, from National Urban League: http://www.nul.org/who-we-are/mission-and-history

Newman, R.P., Smith, S., \& Murphy, R. (2000). A matter of money: The cost and financing of youth development. In N. Jaffe (Ed.), Youth Development: Issues, Challenges and Directions (pp. 82-124). Philadelphia, PA: Public/Private Ventures.

Pittman, K. (1991). Promoting Youth Development: Strengthening the Role of Youth Serving and Community Organizations. Washington, DC: Academy for Educational Development.

Pittman, K., \& Irby, M. (2008). Reflections on a decade of promoting youth development. In A. Y. Forum, The Forgotten Half Revisited: American Youth and Young Families, 1988-2008 (pp. 159-169). Washington, DC: American Youth Policy Forum.

Pittman, K., \& Wright, M. (1991). Bridging the Gap: A Rationale for Enhancing the Role of Community Organizations in Promoting Youth Development. Wahington, DC: Center for Youth Development and Policy Research.

Quinn, J. (2004). Professional development in the youth development field: Issues, trends, opportunities, and challenges. New Directions for Youth Development, pp. 13-24.

Quinn, J. (1999). Where Need Meets Opportunity: Youth Development Programs for Early Teens, the Future of Children. When School is Out .

Salvation Army The History. (2011). Retrieved March 10, 2011, from Salvation Army: http://www.salvationarmyusa.org/usn/www usn 2.nsf/vw-dynamicindex/816DE20E46B88B2685257435005070FA?Opendocument

Save the Children USA. (2011). Retrieved March 10, 2011, from Save the Children USA: http://www.savethechildren.org/site/c.8rKLIXMGIpI4E/b.6115947/k.8D6E/Official Site.htm?mso urce=wexgghp1010

Settersten, R., \& Ray, B. (2010, Spring). What's going on with young people today? The long and twisting path to adulthood. The Future of Children, 20 (1).

Sherraden, M. (1992). Community-based Youth Services in International Perspective. Washington, DC : Carnegie Task Force on Youth Development and Community Programs. 
Silloway, T. (2010). Building Capacity for Better Results: Strategies for Financing and Sustaining the Organizational Capacity of Youth-Serving Programs. Washington, DC: The Finance Project.

Stern, L.W. (1992). Funding Patterns of Nonprofit Organizations that Provide Youth Development Services: An Exploratory Study. Washington, DC.: Carnegie Task Force on Youth Development and Community Programs.

The Y: Yesterday, today, tomorrow for good. (2011). Retrieved June 22, 2011, from The Y: http://www.ymca.net/history/founding.html

Volunteers of America Our History. (2011). Retrieved March 10, 2011, from Volunteers of America: http://www.voa.org/About-Us/Our-History/default.aspx

William T. Grant Foundation Commission on Work, Family, and Citizenship. (1988). The forgotten half: Pathways to success for America's youth and young families. Phi Delta Kappan, $70(4), 280-289$.

Witt, P.A. (2005). Youth serving organizations: Then and now. In P. A. Witt, \& L. L. Caldwell (Eds.), Recreation and Youth Development (pp. 97-128). State College, PA: Venture Publishing, Inc.

YWCA. (2011). Retrieved March 7, 2011, from YWCA:

http://www.ywca.org/site/pp.asp?c=djISI6PIKpG\&b=281372

(C) Copyright of Journal of Youth Development Bridging Research and Practice. Content may not be copied or emailed to multiple sites or posted to a listserv without copyright holder's express written permission. However, users may print, download or email articles for individual use. 